presented with megaloblastic anaemia, histamine fast achlorhydria, gastric atrophy, and low serum $B_{12}$ levels. On treatment with vitamin $B_{12}$ the marrow became normoblastic, but there was no peripheral reticulocytosis; and she died two months later from aplastic anaemia. These authors suggested that underlying aplasia had prevented the anticipated response to vitamin B12.

So far as we are aware aplastic anaemia has not been reported as a complication of true pernicious anaemia per se.

Wright (1963) has pointed out that it is doubtful if phenylbutazone has specific anti-rheumatic properties, and that its main effect is analgesic. Moreover, he claims that no adequate clinical trials have been carried out to compare the analgesic properties of phenylbutazone and aspirin.

It is apparent that whenever phenylbutazone is employed, the patient should be kept under very close clinical and haemtological review.

\section{Summary}

A case of aplastic anaemia occurring in an elderly woman who had taken $10 \mathrm{~g}$. of phenylbutazone over a period of 11 months is reported. The patient was known to have had pernicious anaemia for ten years. The haematological complications of phenylbutazone are briefly reviewed. It is important that any patient receiving phenylbutazone be kept under close haematological review, and the drug be stopped at once should suspicion of selective or general marrow depression arise.

So far as we are aware, however, even such early detection and immediate suspension of the drug may not alter the prognosis in any give case.

We should like to thank Dr. T. Manners for the haematological reports and necropsy details.

\section{REFERENCES}

ANNOTATION (1962): Brit. med. J., i, 459.

Hale, G. S., and DeGruchy, G. C. (1960): Aplastic Anaemia Following the Adminstration of Phenylbutazone, Med. J. Aust., ii, 449.

Humble, J. G. (1964): The Treatment of Aplastic Anaemia with Phytohaemagglutinin, Lancet, i, 1345.

KapliN, S. R. (1955): Aplastic Anaemia due to Butazolidin, Dade County Med. Ass. Bull., 35, 26.

Kersley, G. D., and Mandell, L. (1953): Toxic Effects of Phenylbutazone, Lancet., i, 1046.

LANDER, H., and BonNIN, J. M. (1962): Pernicious Anaemia Associated with Aplastic Anaemia Following Phenylbutazone Therapy, Med. J. Aust., ii, 297.

LeONARD, J. C. (1953): Toxic Effects of Phenylbutazone with Special Reference to Disorders of the Blood, Brit. med. J., i, 1311.

Mauer, E. F. (1955): The Toxic Effects of Phenylbutazone (Butazolidin), New Engl. J. Med., 208, 404.

McCarthy, D. D., and Chalmers, T. M. (1964): Haematological Complications of Phenylbutazone Therapy, Canad. med. Ass. J., 90, 1061.

Rankin, A. M. (1961): A Review of 20 Cases of Aplastic Anaemia, Med. J. Aust., ii, 95.

VenNing, G. R. (1957): Aplastic Anaemia due to Phenylbutazone, Brit. med. J., ii, 146.

Wright, V. (1963): The Treatment of Rheumatoid Arthritis, J. chron. Dis., 16, 83.

WoodlifF, H. J., and DougaN, L. (1964): Acute Leukaemia Associated with Phenylbutazone Treatment, Brit. med. J., i, 744.

\title{
ACUTE MYELOBLASTIC LEUKAEMIA PRESENTING WITH ERYTHEMA NODOSUM
}

\author{
*Myo Thwe, M.B., B.S. (Rgn.), M.R.C.P. (Edin.), D.T.M. \& H. (Eng.). \\ Medical Registrar, Raigmore Hospital, Inverness.
}

ERYTHEMA nodosum associated with leukemia is rare although a few cases have been described. The common cutaneous manifestations are petechial haemorrhages, purpuric spots, prurigolike papules resembling dermatitis herpetiformis, exfoliative dermatitis, and occasionally erythema multiforme. The association of erythema nodosum has been reported with acute monocytic leukemia, (Bluefarb, 1960; Lynch, 1936), with chronic ${ }^{*}$ Present Address:

C/o The Department of Medicine, Wards 5 and 6, Rangoon General Hospital, Rangoon, Burma. lymphatic leukemia (Gate and Cuilleret, 1937); with aleukemic leukemia (Kourilsky, Beauvy and Anglade, 1937); and chronic granulocytic leukemia (Piacentini, 1956; Wintrobe and Mitchell, 1940). Recently a case of erythema nodosum as an initial manifestation of acute stem cell leukemia was published (Pinski and Stansifer, 1964), but there is no published report as yet of its association with acute myeloblastic leukemia. The following case report describes a patient who presented with erythema nodosum and was found to have acute myeloblastic leukemia. 


\section{Case Report}

The patient, a female housekeeper of 58 was admitted to Raigmore Hospital on May 25th complaining of flitting joint pains and painful red nodules on the legs of seven days duration. She said she had felt ill and had developed a sore throat which had been followed by flitting joint pains and finally by red nodules on her legs. She became febrile later with temperatures reaching $102-104{ }^{\circ} \mathrm{F}$. There was no history of recent infection, allergy, or drug ingestion to account for the erythema nodosum. There was no record whatsoever that she had had phenylbutazone (leukaemia after this drug has been reported recently by Chalmers and MoCarthy, 1964).

She gave a past history of having attended the Orthopaedic Clinic in December 1956 for pain in the right elbow, which was diagnosed as tennis elbow, and was treated with intraarticular hydrocortisone. In November 1957 she attended the Medical Clinic with a non-toxic adenoma of the thyroid, but no treatment was given. In November 1960 she was seen again at the clinic, when she had pain and swelling of the proximal interphalangeal joints and the metacarpophalangeal joints.

Investigations: Hb. $66 \%$, ESR $25 \mathrm{~mm}$., WBC $3250 / \mathrm{cu}$. mm., X-ray of the hands revealed early degenerative changes, and she was diagnosed clinically as rheumatoid arthritis although the test for rheumatoid factor was negative.

Progress: She was put on iron therapy and aspirin, and her haemoglobiin improved to $75 \%$, and ESR fell to $17 \mathrm{~mm}$. with considerable gain in weight. On her next visit the ESR was $14 \mathrm{~mm}$., Hb. $83 \%$, and WBC only $3000 / \mathrm{cu}$. $\mathrm{mm}$. She was seen again in 1962 when she had some pain in the joints of the hands. She responded well to a course of short wave diathermy, and her blood examination showed a $\mathrm{Hb}$ of $78 \%$, WBC 4350 cells $/ \mathrm{cu}$. mm., ESR $12 \mathrm{~mm}$., and a negative R.A. Latex test. She was not seen again and remained well till she developed joint pains in May 1964 and was admitted to Raigmore Hospital.

On Admission: The patient did not look very ill on admission despite the high temperature and the joint pains. The positive physical findings were the congested throat and the painful erythematous tender nodules measuring $1-4.5 \mathrm{~cm}$. in diameter over the lower extremeties, and the extensor surfaces of the forearms. Her temperature on admission was $100^{\circ} \mathrm{F}$ and later became intermittent with the temperature rising up to $104^{\circ} \mathrm{F}$. A provisional diagnosis of acute rheumatic fever was made, but in view of the involvement of the small joints of the hand and proteinuria the collagen group of disorders or sarcoidosis were considered more probable. A haematological examination however revealed to our surprise, a white cell count of $259,300 / \mathrm{cu}$. $\mathrm{mm}$. of which $95 \%$ were myeloblasts with $1-4$ nucleoli per cell. $70-90 \%$ of the myeloblasts contained peroxidasepositive granules on peroxidase staining. Hb $8 \mathrm{~g} . /$ $100 \mathrm{ml}$. $(54 \%)$, MCHC $31 \%$, ESR was $100 \mathrm{~mm}$. The blood urea was $37 \mathrm{mg} . / 100 \mathrm{ml}$., normal plasma proteins and electrophoretic pattern, ASO titre less than 12 units, and the throat swab was negative on two occasions. Sternal marrow punoture was carried out which showed the complete replacement of marrow by sheets of blasts cells and confirmed the diagnosis of acute myeloblastic leukaemia.

She was given blood transfusion, and was put on prednisolone and 6-mercaptopurine. The erythema faded considerably two days after the treatment was started, the nodules subsiding and becoming less

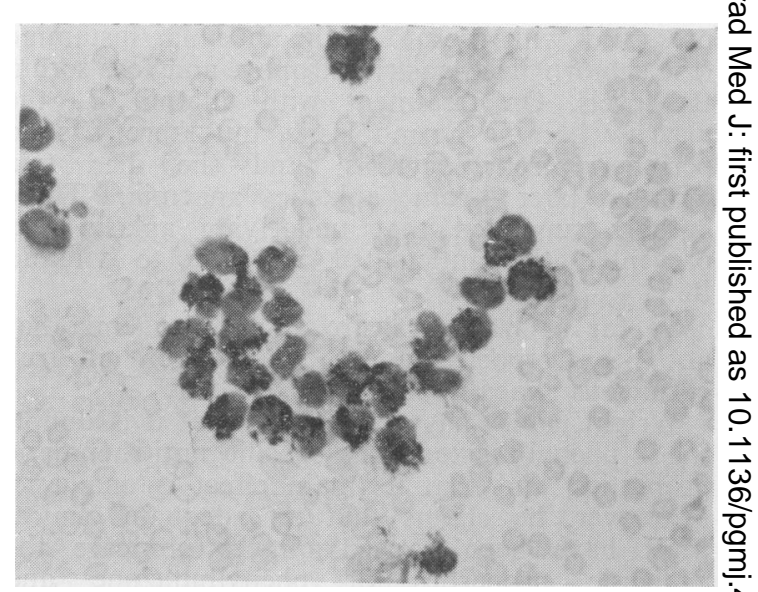

FIG. 1.-Peripheral blood film-peroxidase stainshowing prominent granules in the myeloblasts.

painful, but her general condition deteriorated rapidly. $\vec{\circ}$ Her throat became more inflamed and she developed $\triangle$ chest infection, and despite further treatment with broad spectrum antibiotics she died on the 3rd of $c$ June, three weeks after the first sign of her illness.

Necropsy: The liver weighed $2400 \mathrm{~g}$. and although there was no macroscopic abnormality, microscopic examination revealed extensive leukaemic infiltration $\overrightarrow{0}$ of portal tracts and sinusoids. The bone marros $\mathscr{8}$ was greyish pink in colour and the histological section o showed myeloblastic infiltration. The pulmonad arteries contained leukaemic cell thrombus, probab\$ a terminal phenomenon. No other cause for erythema nodosum was discovered.

\section{Discussion}

Erythema nodosum is a hypersensitivity re- $\stackrel{\varrho}{\Rightarrow}$ action of the skin characterised by a tender $\overline{\bar{O}}$ nodular erythematous eruption in the dermis and subcutaneous tissues, located most commonly over the anterior surface of the legs, occasionally over? the extensor surface of the forearms, and rarely $\bar{\partial}$ on the backs of upper arms, and about the 3 . head, face, and eyes. Recognised causes of $\bar{\sigma}$ erythema nodosum are infective diseases( bacterial, 3 . viral, spirochaetal, and fungal), drugs, and certain $\delta$ diseases of unknown etiology. Infective causes include tuberculosis, streptococcal infection, 0 leprosy, whooping cough, gonorrhoea and bartonellosis, lymphogranuloma venereum, and $\frac{7}{2}$ measles. Other associated disorders are spirochaetal disease like syphilis, and fungal diseases $\mathrm{N}$ like coccidiodomycosis, trichophytosis, and histo- o plasmosis. Drugs causing erythema nodosum $\mathrm{N}$ include iodides, sulphonamides, bromides, sali- N cylic acid, arsenic and phenacetin. It has also $\sigma$ been described in association with sarcoidosis, and ulcerative colitis.

In the above case no known cause for erythema nodosum was discovered. It is interesting to note that when she was seen in 1960 the white cell $\frac{T}{-}$ count was only $3250 / \mathrm{cu}$. mm. Unfortunately the $\stackrel{\mathrm{D}}{\mathbb{D}}$ blood film was not done when the nature of $\stackrel{\mathbb{\rho}}{\mathscr{Q}}$ 
white cells could have been studied. The white cell counts on the next two occasions were also low, being 3000 and $4350 \mathrm{cu} . / \mathrm{mm}$. respectively, the latter in June 1962, but when she was admitted this time in May 1964 the picture was that of acute myeloblastic leukemia. This was a rare presentation of acute myeloblastic leukemia, this diagnosis should be considered as a possibility whenever one is confronted with a case of erythema nodosum.

I wish to express my thanks to Drs. J. Ronald and J. Knox, under whose care the patient was admitted, for permission to publish this report: Dr. R. Saaedand, Sister Ross for all the help; Mr. I. Gordon for haematological investigations, and Mr. W. Rose for the photographs.

\section{REFERENCES}

Bluefarb, S. M. (1960): Leukemia Cutis. Springfield, Illinois: Charles C. Thomas.
Chalmers, T. M., and McCarthy, D. D. (1964): Phenylbutazone Therapy Associated with Leukemia, Brit. med. J., i, 747.

Gate, J., and Cuilleret, P. (1937): A Propos des Manifestations Cutanees des Leucemies, Bull. Soc. franc. derm. syph., 44, 1213.

Kourilsky, P., Beauvy, A., and ANGlade, P. (1937): Leucose Aigue Aleucemique Simulant un Erytheme Noveuxet et Terminee par une Gangrene de la Verge, Bull. Soc. méd. Hôp. Paris, 53, 1378.

LYNCH, F. W. (1936): Cutaneous Lesions Associated with Monocytic Leukemia and Reticuloendotheliosis, Arch. Derm. Syph. (Chic.), 34, 775.

Piacentini, G. (1956): Mielosi Chronica Leucemia ed Eritema Nodoso, Clin. ter., 10, 341.

PinSKi, J. B., and STansifer, P. D. (1964): Erythema Nodosum as the Initial Manifestation of Leukemia, Arch. Derm., 89, 339.

WiNTROBE, M. M., and Mitchell, D. M. (1940): Atypical Manifestations of Leukemia, Quart. $J$. Med., 9, 67.

\title{
ANAEMIA ASSOCIATED WITH PHENOBARBITONE
}

\author{
IRIS I. J. M. GiBson, M.A., M.B., M.R.C.P., (Glasg.), D. Obst., R.C.O.G. \\ The Victoria Infirmary, Glasgow.
}

IT HAS been established that treatment with phenobarbitone may produce a macrocytic blood picture. In 1958 Hawkins and Meynell noted macrocytosis in as many as 34 per cent of a group of epileptics receiving phenobarbitone alone. However only two well documented cases of megaloblastic anaemia due to this drug have been reported. (Chanarin, Laidlaw, Loughridge, and Mollin, 1960; Sherwin, Wait, and Cooper, 1960). The purpose of this paper is to present a third case.

\section{Case Report}

A woman aged thirty six was admitted to the Victoria Infirmary, Glasgow. She had been thought to be normal until sudden right-sided spasticity appeared at the age of four, and epilepsy at five. Since then she had taken phenobarbitone intermittently, and in the last four or five years had taken $180 \mathrm{mg}$. daily, with convulsions at about monthly intervals. She led a sheltered life and was well looked after at home. In 1950 severe burns of face and hands necessitated several plastic operations, and in 1958 she was operated on for deformities of the right arm and leg resulting from the spastic condition.

Three weeks before admission she complained of nausea, vomiting, diarrhoea and weakness. There was heavy menstrual loss with abdominal pain. Her general practitioner treated obvious anaemia but there was no response to intramuscular iron. Pheno-

Present address:

Southern General Hospital, Glasgow. barbitone was continued in usual dosage and $100 \mathrm{mg}$. chlorpromazine given daily for a few days.

Investigations: On admission on September 16th 1963 she was confused and febrile. There was heavy vaginal bleeding. Hb. $2.7 \mathrm{~g}$./ $100 \mathrm{ml}$., RBC 0.69 mill./ cu. mm., PCV $8 \mathrm{ml} . / 100 \mathrm{ml}$., MCV'116 cu. $\mu$, MCHC $34 \%$, WBC $800 / \mathrm{cu}$. mm., reticulocytes $1.2 \%$, platelets $19,000 / \mathrm{cu}$. mm. Films showed well-stained red cells, marked anisopoikilocytosis, and many macrocytes. Macropolycytes were present, and a few megaloblasts. Two pints of group A, rhesus positive blood were given, and serum specimens taken before and after transfusion for vitamin $\mathbf{B}_{12}$ and folic acid activity estimation. Direct Coombs test was negative at a dilution of 1 in 40.

Progress: On the following day her condition allowed sternal marrow aspiration to be done before further transfusion of two pints of blood. Erythropoiesis was megaloblastic, with many extremely early forms, with fine nuclear structure, and obvious nucleoli. Few late forms were seen. Giant metamyelocytes and precursors were present, and the metamyelocytes had abnormal nuclear configuration. Mitotic figures were increased.

While serum estimations were awaited the patient was given $1000 \mu \mathrm{g}$. vitamin $B_{12}$ intramuscularly daily for four days with oral iron and her usual phenobarbitone. A chest infection was treated with intramuscular penicillin. Her condition improved, though heavy vaginal bleeding continued. On September 19th direct Coombs was positive at dilutions of 1 in 5 and 1 in 10 , negative at 1 in 40 . $\mathrm{Hb}$. was $7.4 \mathrm{~g} . / 100 \mathrm{ml}$., reticulocytes $2 \%$, WBC $1,800 / \mathrm{cu}$. mm. (neutrophils 648 ) megaloblasts present in blood film. On September 24th the platelet count was still extremely low at a level of 38,000 per 